\title{
Asthma: a comparison of animal models using stereological methods
}

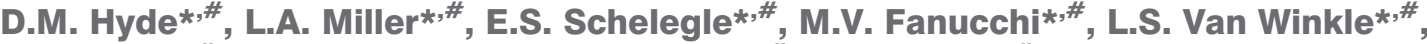 \\ N.K. Tyler*,", M.V. Avdalovic*,", M.J. Evans*,\#, R. Kajekar*\#, A.R. Buckpitt*,+,

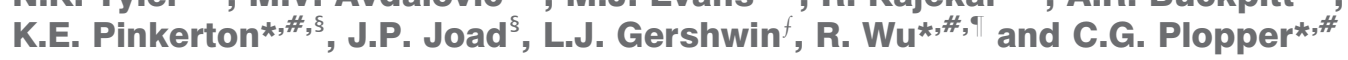

ABSTRACT: Asthma is a worldwide health problem that affects $\mathbf{3 0 0}$ million people, as estimated by the World Health Organization. A key question in light of this statistic is: "what is the most appropriate laboratory animal model for human asthma?"

The present authors used stereological methods to assess airways in adults and during postnatal development, and their response to inhaled allergens to compare rodents and nonhuman primates to responses in humans.

An epithelial-mesenchymal trophic unit was defined in which all of the compartments interact with each other. Asthma manifests itself by altering not only the epithelial compartment but also other compartments (e.g. interstitial, vascular, immunological and nervous). All of these compartments show significant alteration in an airway generation-specific manner in rhesus monkeys but are limited to the proximal airways in mice. The rhesus monkey model shares many of the key features of human allergic asthma including the following: 1) allergen-specific immunoglobulin (Ig)E and skin-test positivity; 2) eosinophils and IgE+ cells in airways; 3) a Thelper type 2 cytokine profile in airways; 4) mucus cell hyperplasia; 5) subepithelial fibrosis; 6) basement membrane thickening; and 7) persistent baseline hyperreactivity to histamine or methacholine.

In conclusion, the unique responses to inhaled allergens shown in rhesus monkeys make it the most appropriate animal model of human asthma.

KEYWORDS: Airway, epithelial-mesenchymal trophic unit, immune/inflammatory cells, respiratory bronchiole

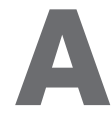
sthma is the most common chronic disease of childhood [1]. Asthma is a worldwide health problem, impacting on both developed and developing countries, which affects 300 million people, as estimated by the World Health Organization (WHO) [2]. Specific age ranges and ethnicities are disproportionately affected. Asthma hospitalisation rates have been highest among African-Americans and children, while death rates for asthma have been consistently highest among African-Americans aged 15-24 yrs [3]. The WHO predicts that asthma deaths will increase by almost $20 \%$ in the next 10 yrs if urgent action is not taken [2]. Asthma is characterised by chronic inflammation, obstruction and remodelling of the airways coupled with breathlessness and wheezing. Episodes of recurrent wheezing, breathlessness, chest tightness and cough are usually associated with airflow obstruction that is often reversible either spontaneously or with treatment. There is also increased bronchial hyperresponsiveness to a variety of stimuli.
The purpose of the present article is to assess the utility of laboratory animals as models of allergic airways disease in humans using stereological methods. First, the biology of the airway within the conceptual framework of the epithelialmesenchymal trophic unit (EMTU) is addressed. The basis of this concept is that all of the cellular and acellular compartments within the airway wall have a close interaction through a series of extracellular signalling cascades, which establish a dynamic homeostatic state. This homeostatic state responds to injury of one component by changing the signalling patterns and the basic functions of all components. Secondly, the differences between species in the organisation of the airway wall are evaluated in adults, the differences in post-natal development of the airways are compared by species, and airway-specific remodelling associated with asthma is evaluated. Thirdly, the current status of understanding of a series of critical issues is assessed regarding the utility of these animal models and their appropriateness
AFFILIATIONS

*California National Primate Research Center,

\#Depts of Anatomy, Physiology and Cell Biology,

${ }^{+}$Molecular Biosciences and ${ }^{f}$ Pathology, Microbiology and Immunology, School of Veterinary Medicine,

-Depts of Medicine and

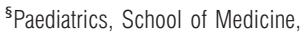
University of California, Davis, CA, USA

CORRESPONDENCE

D.M. Hyde

California National Primate Research Center

One Shields Avenue

University of California

Davis

CA 95616

USA

Fax: 15307546228

E-mail: dmhyde@

primate.ucdavis.edu

SUPPORT STATEMENT

This work was supported by National Institutes of Health grants NIEHS P01ES00628, NIEHS P01 ES11617 and NCRR RR00169. The University of California at Davis is a National Institute of Environmental Health Sciences Center for Environmental Health Sciences (ES05707), which supported core facilities used in the present study.

European Respiratory Review Print ISSN 0905-9180

Online ISSN 1600-0617 
for defining mechanisms as they relate to allergic airways disease in humans. Finally, design-based applications for the analysis of the tracheobronchial airways are addressed as a guide to bringing robust quantitative measures to this field.

\section{THE EPITHELIAL-MESENCHYMAL TROPHIC UNIT}

The concept of the EMTU was developed as a framework for defining the cellular and metabolic mechanisms regulating the response to injury in a complex biological structure, such as the tracheobronchial airway tree [4,5]. Each segment, or airway generation, within the branching tracheobronchial airway tree is addressed as a unique biological entity whose properties may differ from those of neighbouring branches and the intervening branch points. The portions of the airways between branch points are treated as separate biological entities from each other and from the intervening branch points.

All the components of the airway wall, both cellular and acellular, are assumed to play a role in both injury and repair responses and are thought of as compartments (fig. 1). The epithelial compartment of the airway wall is comprised of surface epithelium and submucosal glands. The interstitial compartment includes: the basement membrane zone (BMZ); fibroblasts, including the attenuated fibroblast sheath beneath the basement membrane; smooth muscle; cartilage and the vasculature. The nervous compartment includes the nerve processes, which interdigitate between the vasculature, smooth muscle, subepithelial matrix and epithelium. This includes both afferent and efferent limbs of the nervous system and the central regulating neurons in the brain stem. The vascular compartment includes capillaries, arterioles and venules, primarily from the bronchial circulation, and lymphatic vessels. The immunological compartment includes both migratory and resident inflammatory and immune cells.

The basic assumption of the EMTU is that all of the compartments interact with each other, i.e. the biological function of cells in one compartment is regulated by the

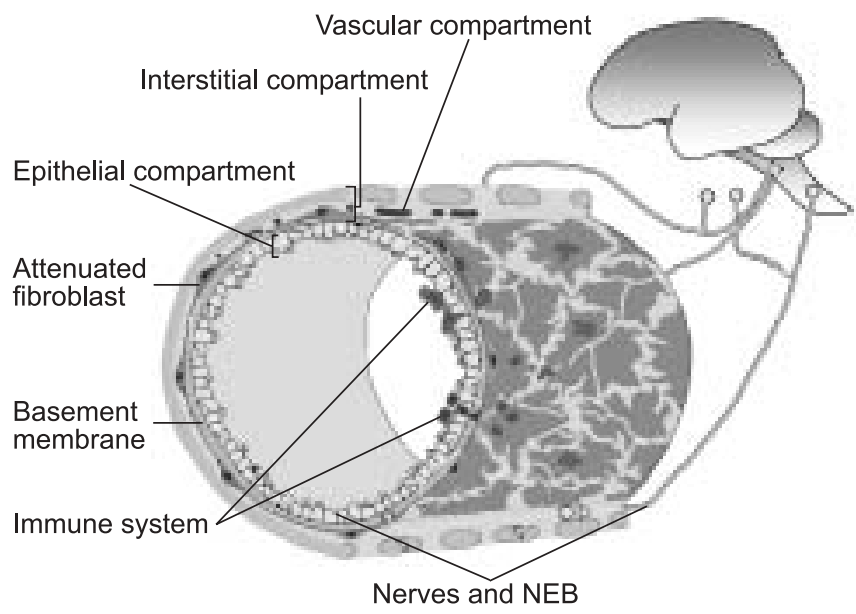

FIGURE 1. Diagrammatic representation of the wall of a tracheobronchial airway with the compartments that vary by species: epithelium, interstitium, nerves (including connections to the central nervous system and neuroepithelial cell bodies (NEB)) and immune/inflammatory cells. The interstitial compartment includes smooth muscle, fibroblasts, blood vessels, cartilage and an extensive basement membrane zone, as found in primates. functions of the cell populations in the other compartments. Perturbation of one compartment creates an imbalance in all compartments [4, 5]. Baseline trophic interaction can be disrupted during acute injury and repair and can be altered by successive cycles of injury, inflammation and repair typical of chronic airway diseases. Asthma manifests itself by altering not only the epithelial compartment or the airway smooth muscle but also other compartments (e.g. interstitial, vascular, immunological and nervous $[6,7])$.

\section{SPECIES DIFFERENCES IN TRACHEOBRONCHIAL AIRWAYS IN ADULTS \\ Tracheobronchial airways}

Architecture

As illustrated in figure 2, the tracheobronchial conducting airways form a complex series of branching tubes that extend to the gas exchange area. The more proximal and larger branches, the bronchi, are usually characterised by the presence of mucous and basal cells in the epithelium, some mucosal glands in the interstitium, and abundant cartilage in the interstitial space. Progressing distally, the smaller bronchioles have thinner walls with little-to-no cartilage, a less complex airway epithelial population, and a greater percentage of smooth muscle compared with the bronchi. In humans and nonhuman primates, cartilage is found in the walls of the tracheobronchial airways, from the trachea distally to the smallest bronchioles (table 1). By contrast, cartilage is found predominantly in the trachea of mice and rats.

The average number of airway generations from the trachea to an alveolarised bronchiole is approximately the same for most mammalian species (table 1). However, branching is relatively unique in primates (including humans and nonhuman primates), with branches separating from the parent airway at $\sim 45^{\circ}$ and being almost uniformly equal in size and in diameter (i.e. dichotomous branching). Branching is monopodial in mice and rats.

The organisation of the transition zone, the area where the conducting airways end and the gas exchange area begins, also differs between species (fig. 2). Primates and carnivores have many respiratory bronchioles, which have a mixture of bronchiolar and alveolar epithelium, compared with other species, such as mice (table 1). As such, the size of the acinus, defined as the terminal (last conducting) bronchiole and all of its distal respiratory airways, is much larger in primates than mice and rats because of the numerous generations of respiratory bronchioles. In fact, there is an $\sim 50$-fold increase in acinar number and a 170-fold increase in acinar volume over the range from the mouse to human lung [12].

Within the gas exchange area of the lung, the ventilatory unit, alveoli and alveolar ducts distal to a single bronchiole-alveolar duct junction changes with species. The diameter of a human ventilatory unit is three-fold greater in humans than mice [12]. The ventilatory unit is the smallest common denominator in determining the distribution of inspired gas to the gasexchange surfaces of the lung.

\section{Cellular composition}

Tracheobronchial airway walls are highly complex cellular structures consisting of many different cell types (fig. 1), which 

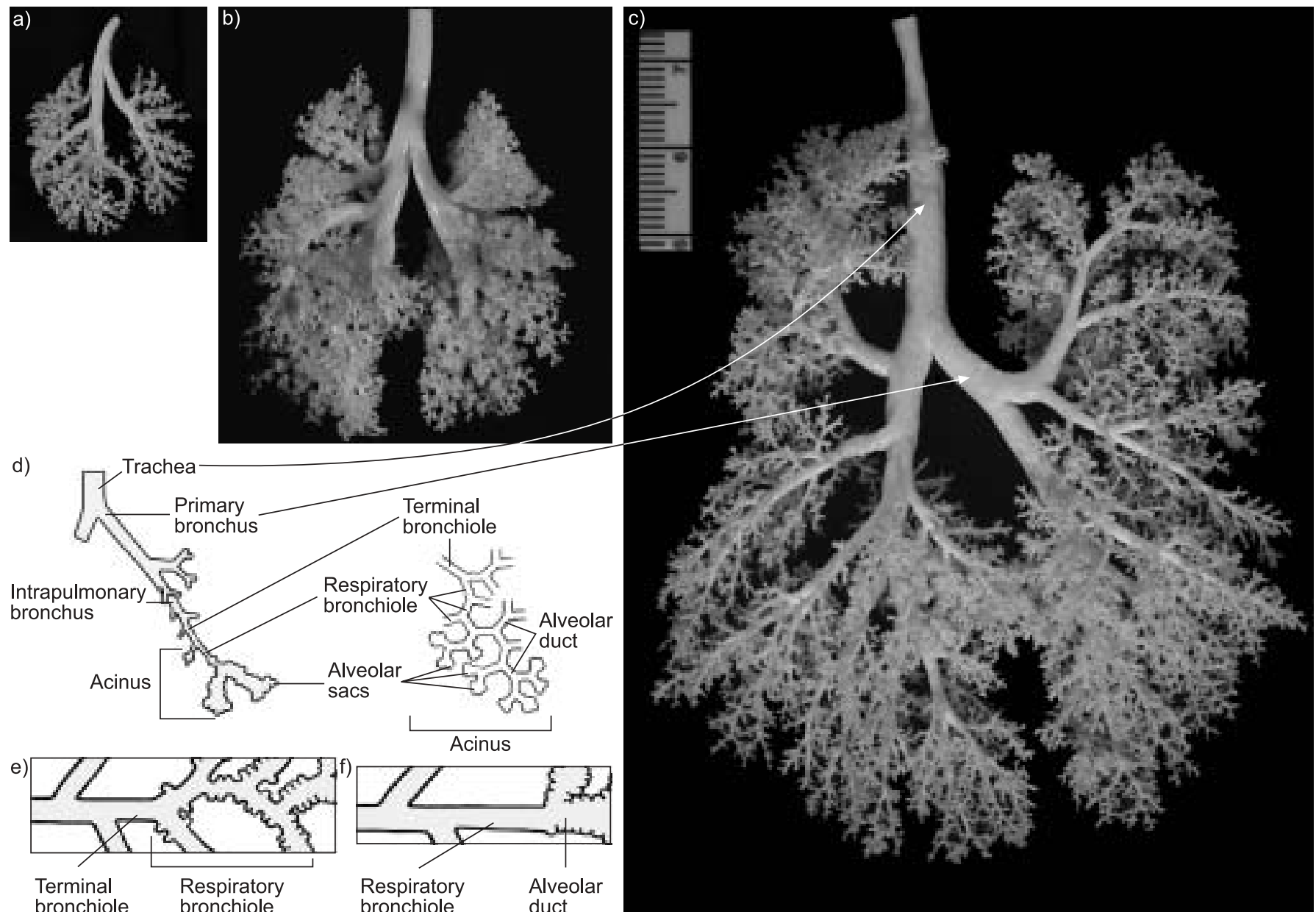

d)

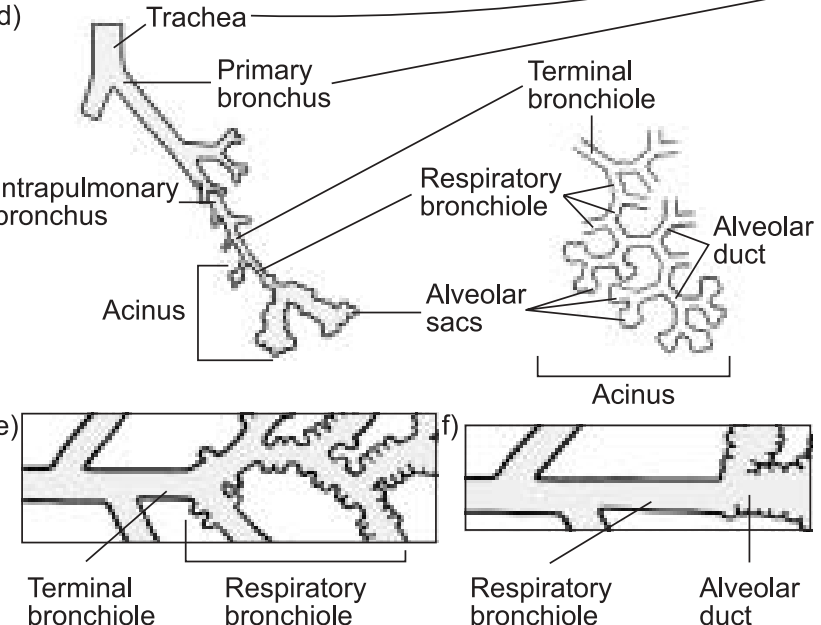

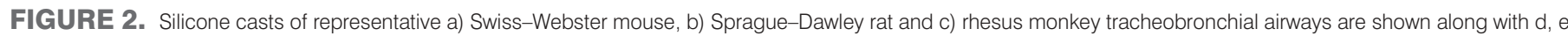

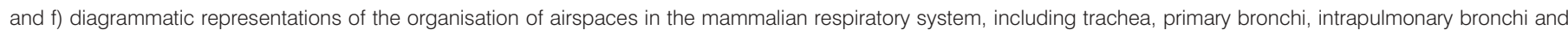

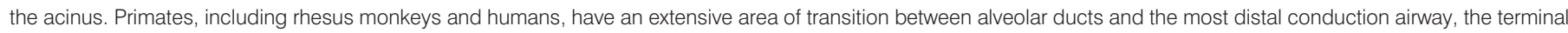

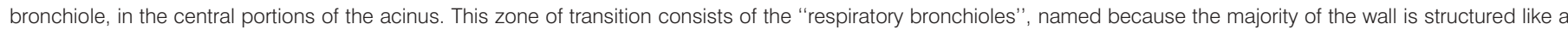

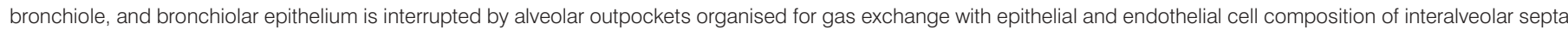

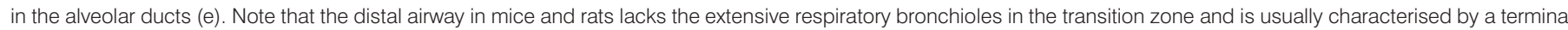

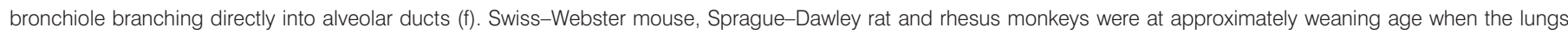
were fixed and the casting material was introduced by negative pressure to fill down to the respiratory bronchioles.

vary in their organisation and cellular composition depending upon species (fig. 3). The interstitium of the tracheal wall of all species contains C-shaped cartilage and there is a band of smooth muscle that joins the open end of the cartilages. However, the trachea and proximal airways of rhesus monkeys and humans have extensive submucosal glands beneath the epithelium, while these glands are present to a variable extent in smaller laboratory species (table 2). There is also a substantial difference in the amount of epithelium that lines the luminal surface in the trachea between species (fig. 3 and table 2). The thickness of the epithelium in the trachea of rhesus monkeys is approximately twice that of mice and onethird to one-half that in humans (table 2).

The trachea demonstrates other major differences between species, such as the composition of the epithelium (table 2). Mucus cells make up a substantial percentage of the airway in primates but do not generally make up a substantial part of the trachea of healthy, pathogen-free mice and rats. The proportion of ciliated cells in the epithelium is relatively similar in all species, yet the proportion of basal cells found in the epithelial surface differs. As would be expected with the differences in secretory cell populations that line the trachea of different species, there is considerable variation in the carbohydrate content of the secretory product (table 3). Alcian blue ( $\mathrm{pH} 2.5)$ periodic acid Schiff's sequence staining was used to demonstrate acid (blue) and neutral (red) mucosubstances. The acidic mucins were characterised as being sulphated using high-iron diamine on an adjacent section [20]. In general, primates have a more heavily sulphated secretory product that is not usually found in laboratory mammals (table 3 ). The difference in secretory product composition is also reflected, to some degree, in the composition of the carbohydrates in tracheal submucosal glands [21]. 
TABLE 1 Comparison of species differences in tracheobronchial airway organisation

\begin{tabular}{|c|c|c|c|}
\hline Parameter & Human & Monkey & Mouse \\
\hline Cartilage in wall & Trachea to distal bronchiole & Trachea to distal bronchiole & Trachea \\
\hline Respiratory bronchioles & Several generations & Several generations & None or one \\
\hline $\begin{array}{l}\text { Generations to alveolarised bronchiole } \\
\text { (axial path) }\end{array}$ & $17-21$ & $13-17$ & $13-17$ \\
\hline
\end{tabular}

Besides the trachea, other airways of the lung demonstrate differences between species in their cellular composition. While smooth muscle is present in the proximal intrapulmonary bronchi of all mammalian species, there is a substantial variation in the extent of cartilage and submucosal glands found in the lobar bronchus of primates and laboratory mammals (table 4). In the most distal conducting airways, the bronchioles, the major differences between species are related primarily to the epithelial surface lining (table 5). Throughout the tracheobronchial airways, mucus cell and basal cells predominate in primates while Clara cells predominate in rodents (tables 2, 4 and 5).

\section{POST-NATAL DEVELOPMENT Epithelial differentiation}

In adult mammals, at least eight cell phenotypes line the tracheobronchial conducting airways, including ciliated cells, basal cells, mucous goblet cells, serous cells, Clara cells, small mucous granule cells, brush cells, neuroendocrine cells and a number of undifferentiated or partially differentiated phenotypes that have not been well characterised. Humans and other primates share a mixture of cell phenotypes not found in nonprimate species, primarily of the secretory cell types [8]. Epithelial differentiation (especially the secretory cell types and glandular elements) occurs post-natally for both rhesus monkeys [13, 23, 24] and humans [25, 26]. The secretory cell population differentiates in a proximal-to-distal pattern, with nearly mature cells lining proximal airways and immature cells in more distal portions. Glandular mucus cells and serous cells differentiate at different times during pre- and post-natal development and through a different sequence of events [13, 23]. This may occur on a different timetable in animals housed in ultra-clean environments [13].

\section{Basement membrane zone}

The BMZ develops post-natally in the airways of nonhuman primates [13, 27] and, apparently, also in humans [28, 29]. Changes include: reorganisation of collagen types I, III and V; a 3-4-fold increase in thickness; shifts in the deposition of perlecan and its storage of fibroblast growth factor (FGF)-2 [27].

\section{Smooth muscle development}

Smooth muscle develops from myoblasts present in the mesenchyme of the developing lung [30,31]. The bulk of smooth muscle growth and differentiation in large bronchi occurs after birth, where it increases four-fold [32, 33]. The process observed in the rhesus monkey as the airways grow post-natally involves changes in orientation of smooth muscle bundles and increases in total bundle number within an airway branch [33]; this maintains the relative density of bundle content. Bundle size is also constant and therefore decreases in relation to airway size as each airway grows. Preterm infants with chronic lung disease have significantly increased amounts of smooth muscle in the larger airways [31].

\section{MUCOCILIARY EPITHELIUM IN RHESUS MONKEYS}

The tracheobronchial airways of rhesus monkeys have been used extensively to define the biology of mucociliary epithelium. The capability of the airways to metabolically activate xenobiotics has been evaluated for both the cytochrome P-450 monooxygenases [34, 35] and flavin-containing monooxygenases [36, 37]. The composition of secretory products has been defined for complex carbohydrates in surface epithelium and glands throughout the airway tree in adults for complex carbohydrates [21, 38-42] and mucin antigens [40]. The expression and distribution of the cystic fibrosis transmembrane receptor [43] and keratins [44] have been characterised in airway epithelium. The pattern for differentiation of tracheobronchial epithelium [13, 24, 45, 46] and submucosal glands has been defined [33]. While regulatory control of epithelial differentiation has been studied in vivo [19], the majority of the work has been carried out using biphasic epithelial cultures. The role of vitamin $\mathrm{A}$ in regulation of epithelial differentiation has been established for: mucin genes [47]; cytokeratins [48], markers of squamous cell differentiation [39]; small proline-rich protein [49-51]; an antioxidant, thioredoxin [52]; the cytokine, interleukin (IL)-8 [53]; epithelial growth factor [54]; and heterogeneous nuclear protein AI [55]. Extracellular calcium also plays a role in epithelial differentiation in vitro [56].

\section{AIRWAY-SPECIFIC RESPONSES TO INHALED ALLERGENS}

Over the past $10 \mathrm{yrs}$, experimental induction of airway remodelling using immune-based models of allergic asthma has increased, especially in mice [57]. However, caution has been stressed concerning the extrapolation of findings from experimentally induced mouse models to naturally occurring human asthma [58, 59]. The immunological basis of both human allergic and mouse models of asthma is an exuberant T-helper cell (Th) type 2 response to one or more allergens. However, there are notable differences between the two 

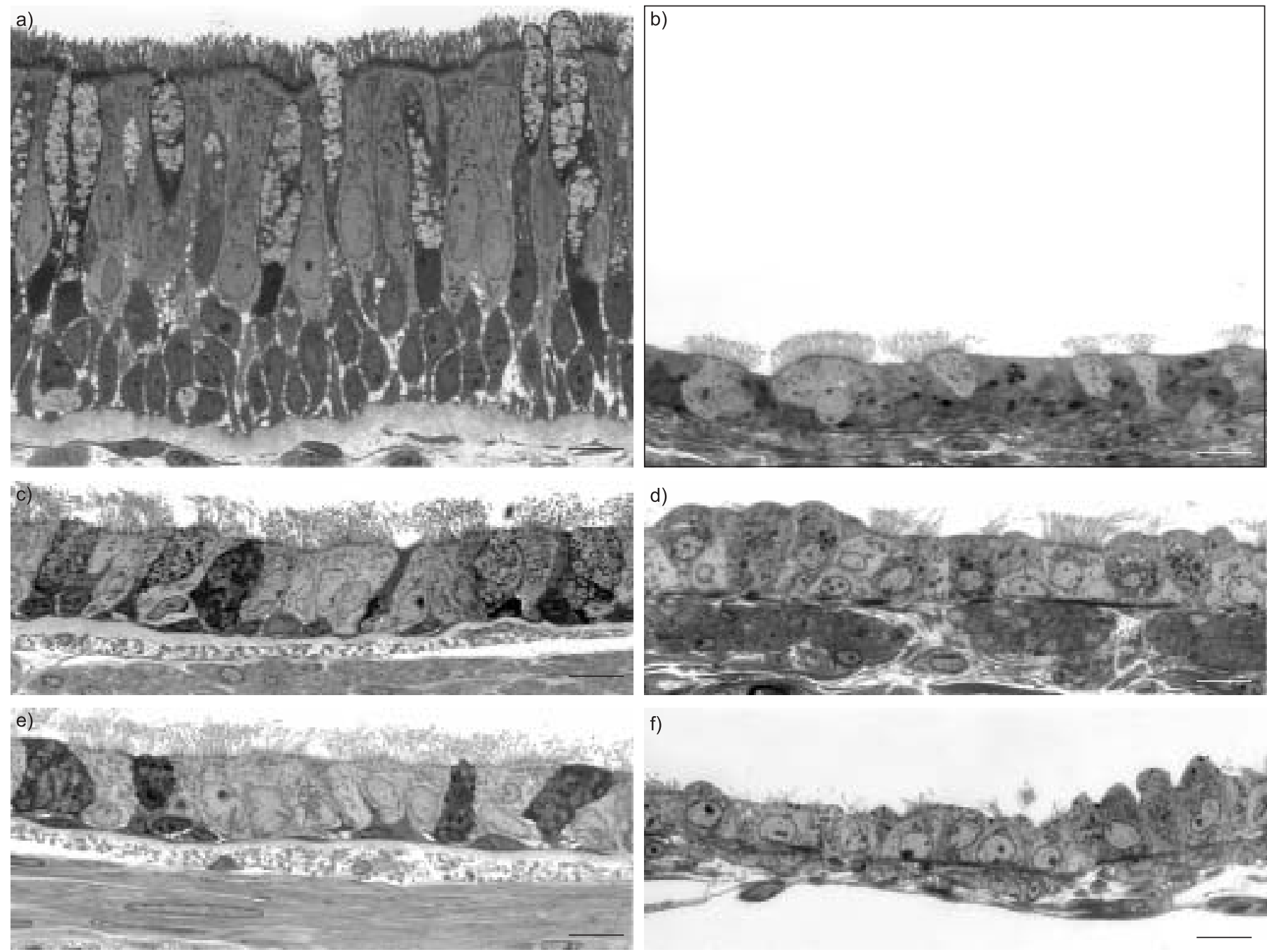

f)
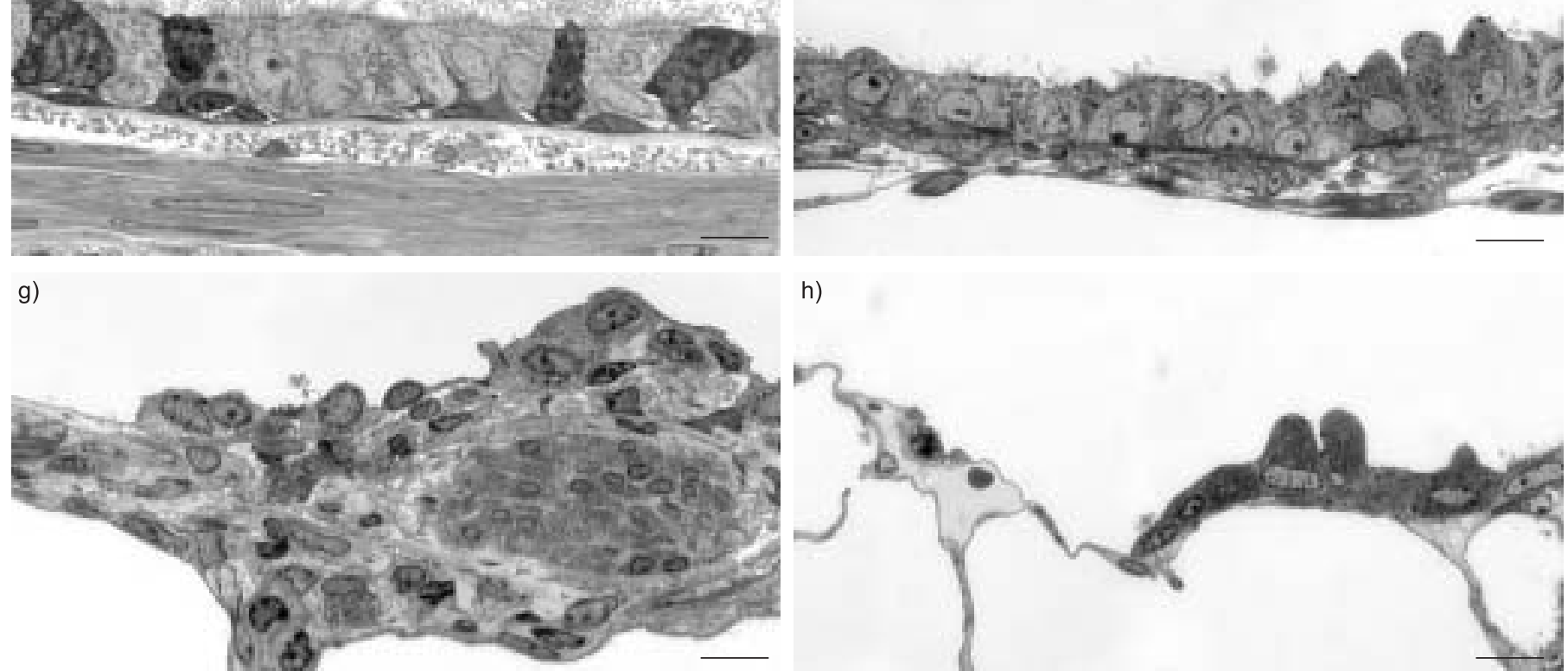

h)

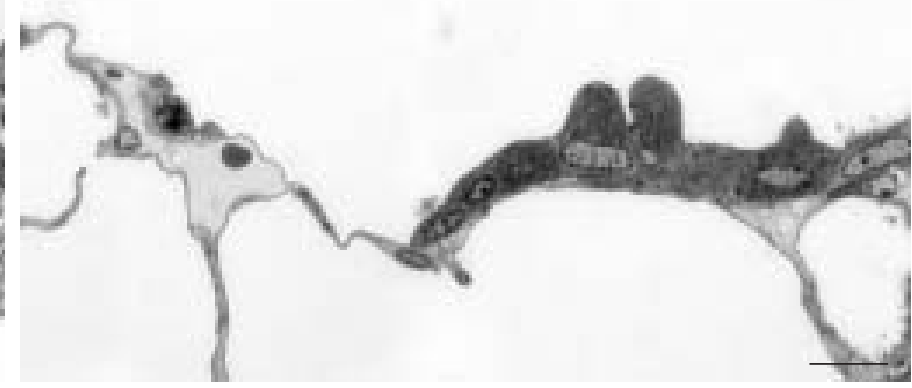

FIGURE 3. Histological comparison of the airspace walls in the same airway generations of an adult male rhesus monkey (a, c, e and g) and an adult male SwissWebster mouse (b, $d, f$ and $h$ ). The luminal airspace (at the top) and the epithelium are set so that the basal lamina matches for both species. The epithelium is more complex and taller in the proximal airways of monkeys than at the same site in mice. Smooth muscle occupies a larger portion of the interstitium in monkeys than mice at all airway levels. All micrographs are at the same magnification (scale bars $=10 \mu \mathrm{m}$ ).

species, including airway development and structure, cellular composition, techniques for measuring pulmonary function, the chronic nature of the disease process and expression of key cytokines and mediators [60]. Furthermore, most mice lack intrinsic airway hyperresponsiveness (AHR). In humans, increases in airway smooth muscle are likely to be the primary mechanism causing AHR, and changes in the extracellular matrix may stimulate smooth muscle growth and contribute to the mechanics of airway obstruction. The classic chicken-egg ovalbumin (OVA) intraperitoneal immunisation with alum, followed by repetitive challenge with OVA intranasally, produces a robust eosinophilic inflammatory response around 


\begin{tabular}{|c|c|c|c|}
\hline $\begin{array}{cc}\text { TABLE } 2 & \text { Compar } \\
\text { trachea }\end{array}$ & of speci & differen & ces in cells of the \\
\hline Parameter & Human & Monkey & Mouse \\
\hline \multicolumn{4}{|l|}{ Wall } \\
\hline Smooth muscle & Present & Present & Present \\
\hline Cartilage & Present & Present & Present \\
\hline Submucosal glands & Present & Present & Present (proximal $1 / 3$ ) \\
\hline \multicolumn{4}{|l|}{ Epithelium } \\
\hline Thickness $\mu \mathrm{m}$ & $50-100$ & 20-30 & $11-14$ \\
\hline Cells per mm basement & $303 \pm 20$ & & \\
\hline membrane & & $181 \pm 51$ & 215 \\
\hline Mucous goblet cells \% & 9 & 17 & $<1$ \\
\hline Serous cells \% & & $<1$ & $<1$ \\
\hline Clara cells \% & & $<1$ & 49 \\
\hline Ciliated cells \% & 49 & 33 & 39 \\
\hline Basal cells \% & 33 & 42 & 10 \\
\hline Other cells \% & & 8 & 1 \\
\hline
\end{tabular}

bronchi and allergen-dependent AHR, dependent on CD4+ T-lymphocytes via IL-4, but independent of IL-5, immunoglobulin (Ig)E, or both [61,62]. However, there are other unique features of allergic airways disease that are found in humans but not mice: a lack of intrinsic AHR (except in the A/J mouse strain), smooth muscle hypertrophy in the more distal bronchi and respiratory bronchioles, exfoliation of epithelial sheets, and mast cell infiltration of airway smooth muscle [60].

\section{UNIQUENESS OF THE RHESUS MONKEY MODEL OF ASTHMA}

Large animal models of asthma have been developed in sheep [63], dogs [64] and nonhuman primates (macaques) [65-69]. The rhesus monkey model of asthma is used because of the genetic and physiological similarity to humans that allows pulmonary function measurements commonly used in humans [66]. The airway anatomy and especially the similarities during post-natal development of the lung are another major advantage in using rhesus monkeys [70]. The rhesus monkey also has more specific reagents available for use compared with other nonhuman primates [71]. The model involves injection of a common human allergen, followed by intranasal instillation and repeated aerosol challenges of the allergen. The rhesus monkey model shares many of the key features of human allergic asthma, including: allergen-specific $\operatorname{IgE}$ and skin-test positivity, eosinophils and IgE+ cells in airways, a Th2 cytokine profile in airways, mucus cell hyperplasia, subepithelial fibrosis, basement membrane thickening and persistent baseline hyperreactivity to histamine or methacholine [66, 67, 72].

The house dust mite allergen (HDMA)-rhesus monkey model shows the following: Th2-associated cytokine and chemokine induction; migration of eosinophils, lymphocytes and dendritic cells into airways; early and late bronchoconstriction responses; and enhanced reactivity to histamine challenge in response to HDMA challenge [66, 72].

The HDMA-rhesus monkey model was developed by a multidisciplinary group of investigators at the California

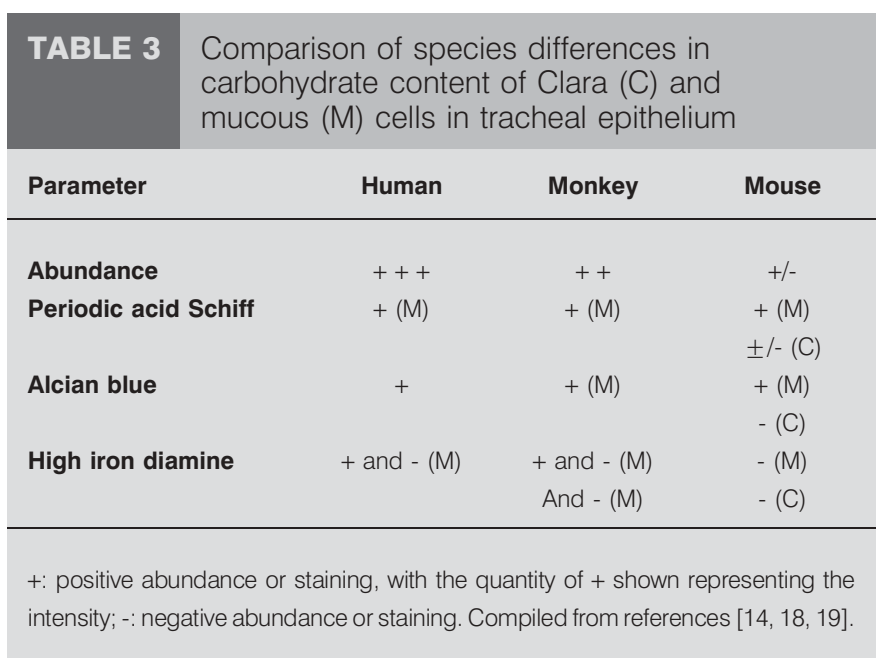

National Primate Research Center (University of California, Davis, CA, USA) to address the problem of environmental enhancement of the induction of asthma. A number of discoveries about asthma using the rhesus monkey model have been made.

\section{Airway physiology}

Following aerosol challenge with HDMA, sensitised rhesus monkeys show cough and rapid shallow breathing, and increased airway resistance, which can be reversed by albuterol aerosol treatment. Compared with nonsensitised monkeys, there is a four-fold reduction in the dose of histamine aerosol necessary to produce a $150 \%$ increase in airway resistance in sensitised monkeys [66].

\section{Airway generation-specific immune and inflammatory cells and cytokines}

After aerosol challenge, serum levels of histamine are elevated in sensitised monkeys. Sensitised monkeys also exhibit increased levels of HDMA-specific IgE in serum, numbers of eosinophils and exfoliated cells within lavage, and elevated CD25 expression on circulating CD4+ lymphocytes [66]. In HDMA-challenged monkeys, the volume of CD1a+ dendritic cells, CD4+ Th lymphocytes, CD25+ cells, IgE+ cells, eosinophils and proliferating cells are significantly increased in the airways. All of these cell types accumulate within airways in unique patterns of distribution, suggesting compartmentalised responses with regard to trafficking. Although cytokine mRNA levels are elevated throughout the conducting airway tree of HDMA-challenged animals, the distal airways (terminal and respiratory bronchioles) exhibit the most pronounced upregulation [73].

\section{Airway generation-specific remodelling}

Intrapulmonary proximal and distal bronchi of sensitised and challenged monkeys have focal mucous goblet cell hyperplasia, thickening of the BMZ, hypercellularity in the epithelium and subepithelial connective tissue, and increases in smooth muscle and bronchial microvessels $[6,66]$. These changes are site-specific and vary greatly within various portions of the airway wall in the same airway generation, between airway generations in an individual sensitised and challenged animal, and from animal to animal in the sensitised and 


\begin{tabular}{|c|c|c|c|c|}
\hline \multirow{2}{*}{$\begin{array}{l}\text { TABLE } 4 \\
\text { Parameter }\end{array}$} & \multicolumn{4}{|c|}{$\begin{array}{l}\text { Comparison of species differences in proxima } \\
\text { intrapulmonary airways }\end{array}$} \\
\hline & & Human & Monkey & Mouse \\
\hline \multicolumn{5}{|l|}{ Wall } \\
\hline \multicolumn{2}{|c|}{ Smooth muscle } & Present & Present & Present \\
\hline \multicolumn{2}{|l|}{ Cartilage } & Present & Present & Absent \\
\hline \multicolumn{2}{|c|}{ Submucosal glands } & Present & Present & Absent \\
\hline \multicolumn{5}{|l|}{ Epithelium } \\
\hline \multicolumn{2}{|c|}{ Thickness $\mu \mathrm{m}$} & $40-50$ & 27 & $8-16$ \\
\hline \multicolumn{5}{|c|}{ Cells per mm basement } \\
\hline \multicolumn{2}{|c|}{ membrane } & NA & 175 & 109 \\
\hline \multicolumn{2}{|c|}{ Mucous goblet cells \% } & 10 & 15 & $<1$ \\
\hline \multicolumn{2}{|c|}{ Serous cells \% } & 3 & 5 & $<1$ \\
\hline \multicolumn{2}{|c|}{ Clara cells \% } & & & 61 \\
\hline \multicolumn{2}{|c|}{ Ciliated cells \% } & 37 & 47 & 36 \\
\hline \multicolumn{2}{|c|}{ Basal cells \% } & 32 & 32 & $<1$ \\
\hline \multicolumn{2}{|l|}{ Other \% } & 18 & 2 & 2 \\
\hline
\end{tabular}

Data from references $[9,13-15,17,18]$. NA: not available.

challenged group. A mouse model of allergic airways did not show airway generation-specific remodelling using airways microdissection-based sampling, but did show changes in the proximal airways that were significantly different from control mice [74].

\section{Epithelial changes in asthma}

A characteristic of asthma is the sloughing of sheets of columnar epithelium from the airways, leaving basal cells attached to the basal lamina [75-77]. The desmosomal attachments between sloughed epithelial cells are intact, suggesting that failure of the desmosomal attachment between basal and columnar cells is responsible for sloughing of airway epithelium in asthmatic subjects [78, 79]. Recently it was shown that a reduction in the anchoring mechanisms between columnar cells and basal cells does exist in the airways of asthmatic humans [80,81]. Whether this change combined with the inflammatory and immune cell trafficking is responsible for cell sloughing is not known. To study this response, an animal model must be used that includes a multilayered epithelium, resembling the human epithelium, with abundant basal cells throughout the majority of the airway tree. Basal cells are more sparsely distributed in mice than in the rhesus monkey.

Goblet cell hyperplasia is also a characteristic of asthmatic airways [67, 82]. Goblet cells are generally not sloughed from the airways, as are the ciliated cells, suggesting that they are more firmly attached to the basal cells. In asthma and other chronic airway diseases, the number of goblet cells increase and ciliated cells decrease, suggesting that the process of differentiation following repair of cell loss has been compromised. A mouse model of allergic airways showed that a 75\% decrease in Clara cells and a 25\% decrease in ciliated cells were completely compensated for by an increase in mucus cells [74]. Consequently, by day $22,70 \%$ of the total epithelial cell population in the proximal airways was mucus cells. Electron microscopy illustrated that Clara cells were undergoing metaplasia to mucus cells and 1:5 to 1:10 of the mucus cells were proliferating. Epithelial cell death (necrosis or apoptosis) did not appear to be the stimulus driving epithelial proliferation and the increase in mucus cell numbers was primarily a result of Clara cell metaplasia. These epithelial changes were not significant in the distal mid-level airway and bronchiole. In contrast, chronic exposure to OVA (2 consecutive days per week for 12 weeks) resulted in goblet cell hyperplasia into the distal airways of mice [63]. It does appear, however, that the epithelial changes in the airways of allergic mice are unique to the high number of Clara cells in their epithelium.

\section{Airway wall matrix/basement membrane}

A characteristic of asthma is a massive increase in BMZ thickness [83]. The BMZ is the central structure of the EMTU [4, 84]. Exchange of information between the epithelium and fibroblasts occurs via the basal lamina: the lamina lucida, the lamina densa and the lamina reticularis. The BMZ is a region specialised for the attachment of the epithelium with the matrix [85, 86]. Epithelial cells are attached to the lamina densa, which in turn is attached to the underlying collagen of the lamina reticularis. The lamina reticularis is especially pronounced under the respiratory epithelium of large conducting airways, where it may be several micrometres thick and composed of heterogeneous fibres (collagens type I, III and $\mathrm{V})$. Attenuated fibroblasts beneath the BMZ are thought to synthesise the collagen components of the BMZ [4, 5, 84]. Remodelling of the epithelial BMZ, such as occurs in asthma, involves increased deposition of collagen in the BMZ [28, 87, 88]. Thickening of the BMZ is thought to protect against airway narrowing and air trapping [89].

The BMZ has a number of functions in the EMTU. Besides being specialised for attachment of epithelium with the extracellular matrix, it also has the following functions: 1) it serves as a barrier; 2) it binds specific growth factors, hormones and ions; 3 ) it is involved with electrical charge; and 4) it plays a critical role in cell-cell communication [90, 91]. Heparan sulphate proteoglycans (perlecan) and chondroitin sulphate proteglycans (bamacan) are an intrinsic part of the BMZ that are involved with most of its functions [92]. Binding and storage of growth factors by perlecan (mainly FGF-2) is also an important function of the BMZ. FGF-2 is the main growth factor stored in the BMZ through binding with perlecan, an intrinsic constituent of the BMZ. FGF-2 is a ubiquitous multifunctional growth factor that has a variety of functions as a regulator of growth and differentiation. It is thought to be stored in the BMZ for rapid cellular responses to changes in local environmental conditions. FGF-2 forms a ternary signalling complex with the cell surface receptors FGFR-1 and syndecan-4. In the airway, these receptors are found only on basal cells [93].

The following occurs in the rhesus monkey: 1) FGF-2 is associated with synthesis of the BMZ in development and injury; 2) perlecan regulates FGF-2 and is necessary for normal development of the BMZ; and 3) the molecular signal associated with a thick BMZ persists during recovery [94]. However, the role of FGF-2 released from the BMZ and its interactions with basal cells of the airway epithelium has not been determined. In chronic exposure to OVA, mice show markedly increased levels 
TABLE 5 Comparison of species differences in terminal bronchioles

\begin{tabular}{|c|c|c|c|}
\hline Parameter & Human & Monkey & Mouse \\
\hline \multicolumn{4}{|l|}{ Wall } \\
\hline Cartilage & Absent (bifurcation) & Absent (bifurcation) & Absent \\
\hline Submucosal glands & Absent & Absent & Absent \\
\hline \multicolumn{4}{|l|}{ Epithelium } \\
\hline Thickness & ? & $?$ & $7-8$ \\
\hline Serous cells \% & 35 & $\sim 20$ & 0 \\
\hline Clara cells \% & & & $60-80$ \\
\hline Ciliated cells \% & 52 & $\sim 50$ & $40-20$ \\
\hline Basal cells \% & $<1$ & $\sim 10$ & $<1$ \\
\hline Other \% & 13 & $\sim 5$ & 0 \\
\hline
\end{tabular}

?: not known. Data from references $[8,11,14,16,22]$.

of transforming growth factor (TGF)- $\beta$ and subepithelial fibrosis throughout the airway tree [62].

\section{Mesenchymal cells}

Attenuated fibroblasts are a distinct morphological category of cells lying directly under the epithelium of the conducting airways of humans and rhesus monkeys $[28,84]$. They exist as a layer of large flat cells covering $\sim 70 \%$ of the BMZ [84]. In the bronchi of normal humans, these cells also exist as a discontinuous layer comprised of attenuated fibroblasts and myofibroblasts. In asthmatics, the number of myofibroblasts in this fibroblast layer is more than double that of normal individuals and the cell layer is more than twice as far from the epithelial basal lamina due to subepithelial fibrosis [28]. The functional role of this layer of cells is not known. Attenuated fibroblasts play a pivotal role in the pathogenesis of asthma based upon morphological evidence of subepithelial fibrosis in asthmatic human airways and the well-known role of collagen produced by these cells in tissue compliance and mechanics. The same appears to be the case for the rhesus monkey.

The mechanism of increased smooth muscle associated with asthma in humans is unknown. However, TGF- $\beta 1$ is associated with airway smooth muscle remodelling in the OVA mouse model of allergic airways disease [62, 95]. Smooth muscle hypertrophy and hyperplasia is a characteristic of the distribution of airway smooth muscle in remodelling airways in humans [96]. Type 1 asthmatics have increased smooth muscle mass only in large bronchi, mainly due to hyperplasia. Type II asthmatics have smooth muscle thickening from large bronchi to small bronchioles, due to both hypertrophy and hyperplasia. It is not known whether these differences are due to co-exposure to air pollution, a phenotypic difference in myocytes by airway level or differences in the impact of the allergen response on different stages of post-natal airway development. Increases in airway smooth muscle may increase airway contractility as is found in airway hyperresponsiveness $[97,98]$ and in airways taken from asthmatic patients [99]. The same is true for infant rhesus monkeys with allergic airways disease, which also exhibit altered orientation and increases in muscle bundle mass [100]. Increased airway smooth muscle is a hallmark of asthma but whether environmental factors, such as HDMA allergen or ozone exposure, can cause this increase by altering development in neonates or repair in adults can best be defined in a species with an extensive period of postnatal airway development, such as the rhesus monkey.

\section{Bronchial vasculature}

Bronchial and pulmonary vasculatures are important pathways where growth factors and nutrients that are needed for lung growth and maturation, and inflammatory cells are delivered to the lung. The bronchial vasculature of the EMTU contributes to the development of the human asthma phenotype via microvascular leakage and delivery of inflammatory mediators and leukocytes in the airways, and is a prerequisite for airway remodelling in bronchial asthma. Studies in patients with asthma have described an increase in bronchovascular density; in conjunction with this finding, patients with asthma have been shown to have elevated vascular endothelial growth factor (VEGF) in their sputum and VEGF-producing cells in the mucosa assessed by endobronchial biopsy [101]. Transgenic mice that overproduce VEGF have a two-fold increase in tracheal vascular density and an enhanced Th2 immune response to allergen [102]. Although the role of VEGF as an important mediator for the angiogenic events in allergic asthma is established, the cellular and molecular mechanisms that regulate VEGF and its receptors' expression are not well defined. Airway physiology and vascular density have been linked in multiple different studies. It is thought that increased vascularity leads to bronchial constriction and airway narrowing [103, 104]. Even patients with impaired left ventricular function have been shown to have increased airway hyperreactivity [105]. Rhesus monkeys with HDMA-induced allergic airways also show an increase in airway generation-specific bronchovascular density [6].

These studies $[6,66,72]$ demonstrate that allergic asthma can be produced experimentally in a nonhuman primate, the rhesus macaque monkey, using a recognised human allergen, house dust mite, and provides a valuable model for human asthma. 


\section{Design-based stereological approaches to the tracheobronchial airways}

A common problem observed in lung stereology is profile counting of cells as a representation of cell number. An example of the problems associated with profile counting either per unit area or per unit length of the epithelial basal lamina was demonstrated during development of the bronchiolar epithelium in rabbits (table 6) [106]. Ciliated cells have nuclei with a larger volume than nonciliated bronchiolar cells during most of bronchiolar development. This volume difference results in more ciliated cell profiles than nonciliated cell profiles simply because of the size difference. This significant bias can introduce as much as a $6 \%$ overestimation error in the number of ciliated cells, even though they represent only a third of the cell population. Whether estimates are made based on numbers per airway generation or total numbers within the lung, design-based methods should be used and insurance should be made that the numbers represent the whole unit (either airway generation or lung). More efficient design-based methods for estimation of cell numbers are now available using a "disector" [107]. These are used widely to provide accurate estimates of cell numbers during injury and repair of conducting and distal airways [108, 109]. These methods are critical because, as illustrated in table 6, profile counts are not equivalent to number counts in three-dimensional volume and should be avoided as an endpoint because of their inherent bias. The disector approach can be used with thick sections and viewed with a brightfield or laser confocal microscope that optically focuses through the section [109]. The usual section thickness is $30-50 \mu \mathrm{m}$ and a short depth of focus (usually $\sim 1 \mu \mathrm{m}$ ) is essential to optically section the tissue using a light microscope. A length gauge is required to record the distance moved in the $\mathrm{Z}$ direction. This unbiased counting method, called an optical disector, is direct and efficient, provided an unbiased counting frame is used [110] and the counting frame concept is extended by excluding structures counted on either the top or bottom of the counting cube. The reference volume $(V(\mathrm{r}))$ is estimated by pointcounting an optical section at the top of the disector that provides a reference area that is multiplied by the distance travelled in the $\mathrm{Z}$ direction for counting structures. The following formula is used to estimate the number of features of interest per reference volume:

$$
N V(\mathrm{i}, \mathrm{r})=Q^{-} i / A \mathrm{r} \cdot h
$$

where $Q^{-} i$ is the feature count, $A \mathrm{r}$ is the reference area and $h$ is the height of the disector. An optical disector requires feature identification because of lack of resolution and, therefore, immunohistochemistry is often used to identify specific cell types. A physical disector is used when higher resolution and morphological characteristics are relied on for feature identification (fig. 4). In general, disector height should not be $>0.75 h$ of the smallest feature to be counted. The same formula is used as for the optical disector previously discussed. The sections of a physical disector are as thin as possible for the greatest resolution, and the top section is used as the counting section. The bottom section is used as the lookup section. Only those features intersecting the counting section are counted; thus, the height of the disector is the thickness of the counting section and the distance to the lookup section. An unbiased counting frame is also used on the counting section [110]. A disector count can be combined with a fractionator to provide an unbiased estimate of the total number of features in the lung or airway generation:

$$
\mathrm{n}=(1 / \text { bsf }) \cdot(1 / \text { ssf }) \cdot(1 / \text { asf }) \cdot(1 / h s f) \cdot Q^{-}
$$

where the fractions are as follows: bsf: block sampling fraction; ssf: section sampling fraction; asf: area sampling fraction; hsf: height sampling fraction; and $Q^{-}$: feature count within the sampled fraction.

The smooth fractionator [111] can be used to sample the entire lung [112] or subcompartments of the lung, such as specific airway generations (fig. 5). Airways are best sampled using vertical sections because this allows identification of the epithelial and interstitial compartments from an apical to basal arrangement, respectively. In vertical sections, the orientation of the tissue is known relative to the stereological probe so that orientation bias is correctable [113]. When vertical sections are used for airways, a cycloid test system (stereological probe with a known orientation) can be used to provide correct estimates of surface and length (the two measures that are orientation dependent). The smooth fractionator is unbiased

TABLE 6 The nuclear size and percentage of nonciliated and ciliated bronchiolar epithelial cells at 30 days of gestation and 4

\begin{tabular}{|c|c|c|c|c|c|c|}
\hline & \multicolumn{3}{|c|}{ Nonciliated bronchiolar cells } & \multicolumn{3}{|c|}{ Ciliated cells } \\
\hline & 30 days & 4 weeks & 17 weeks & 30 days & 4 weeks & 17 weeks \\
\hline$D n \mu m$ & 8.1 & 6.7 & 6.2 & 9.0 & 7.0 & 7.2 \\
\hline NL n per $\mathrm{mm} \%$ & 86 & 78 & 61 & 14 & 22 & 39 \\
\hline NA $n$ per $\mathrm{mm}^{2} \%$ & 86 & 77 & 61 & 14 & 23 & 39 \\
\hline $\mathrm{Nv}$ n per $\mathrm{mm}^{3} \%$ & 90 & 78 & 67 & 10 & 22 & 33 \\
\hline$\Delta 3 \mathrm{D} \rightarrow 2 \mathrm{D} \%$ & -4 & -1 & $-6^{\#}$ & +4 & +1 & $+6^{\#}$ \\
\hline
\end{tabular}
and 17 weeks of post-natal age in rabbits

Dn: mean calliper diameter of epithelial cell nuclei; nL: number of nuclear profiles per length of airway; nA: number of nuclear profiles per area of epithelium; nv: number of nuclei per volume of epithelium; $\Delta 3 \mathrm{D} \rightarrow 2 \mathrm{D} \%$ : the percentage of change from size-weighted estimates of $\mathrm{nL}$ and $\mathrm{nA}$ as compared with the unbiased estimate of $\mathrm{nv}$ [106].

\# : significant difference between two-dimensional and three-dimensional estimates. 

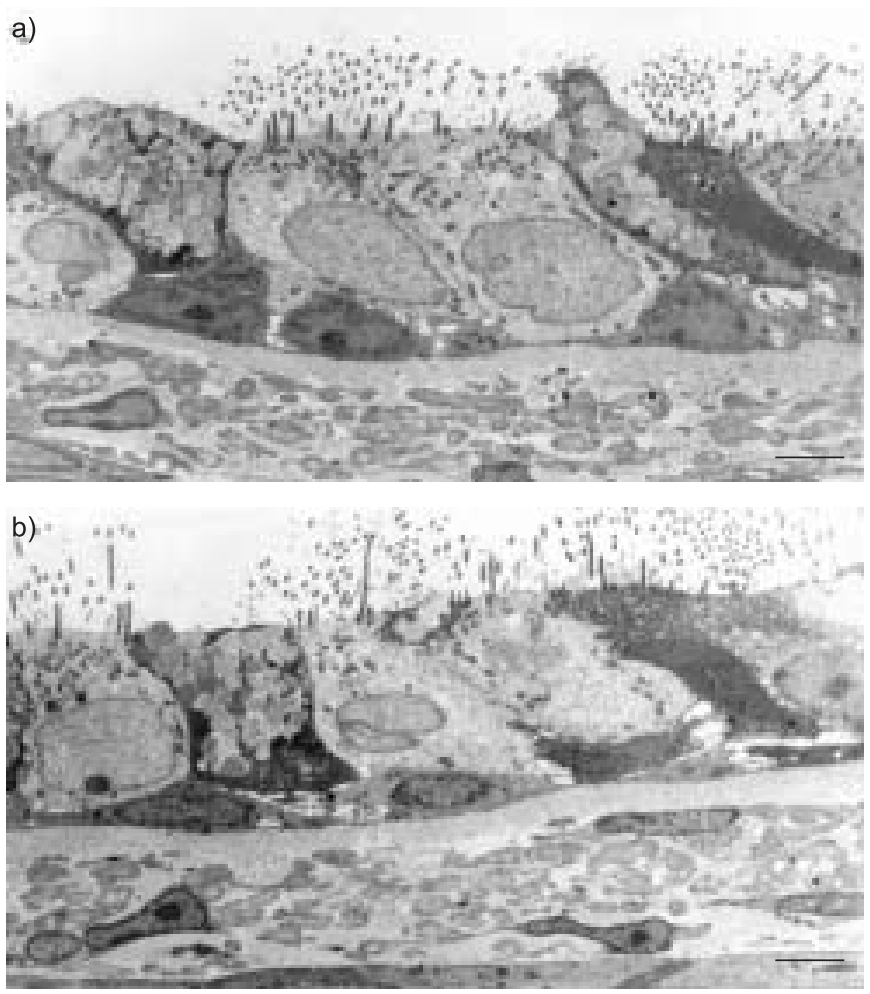

FIGURE 4. Two transmission electron micrographic 60-nm sections comprise a $5-\mu \mathrm{m}$ physical disector imaged using a transmission electron microscope. a) Shows the counting section and b) the look-up section. Of the two ciliated cells in the centre of $a$ ), the one on the right is counted because its nucleus is not present in the look-up section, whereas the ciliated cell to the left is not counted because its nucleus is present in the look-up section. Scale bars $=5 \mu \mathrm{m}$.

because all the compartments of the airway or lung have an equal chance of being sampled [111].

\section{Statistical efficiency in lung stereology}

Knowledge of the components comprising biological variation in airways or the entire lung is the key to experimental design (number of animals, tissue samples, fields per slide, frame size, points and line length per test system to estimate a particular structural feature). The equation for optimal statistical efficiency in stereology is:

$$
O C V 2(X)=C V 2(X)+\operatorname{mean}[C E 2(X)]
$$

where $\operatorname{OCV} 2(\hat{X})$ is the observed coefficient of variation, $C V 2(X)$ is the true biological variation (unknown) and mean $[C E 2(X)]$ is the estimate of the sampling and stereological variation [114]. A general goal for optimal statistical efficiency in stereology is to consider the coefficient of error of the stereological variability ( $\mathrm{CE}^{2}$ stereological) in relation to the coefficient of variability of the biological variability $\left(\mathrm{CV}^{2}\right.$ biological) as follows:

$$
\mathrm{CE}^{2} \text { stereological } \leqslant 1 / 2\left(\mathrm{CV}^{2} \text { biological }\right)
$$

Contributions to sampling and stereological variation to direct volume estimates using the Cavalieri method have been provided by CRUZ-ORIVE [115] and in a nomogram by GUNDERSEN and JENSEN [116]. Contributions to stereological variation for ratio estimators, such as volume, number, and

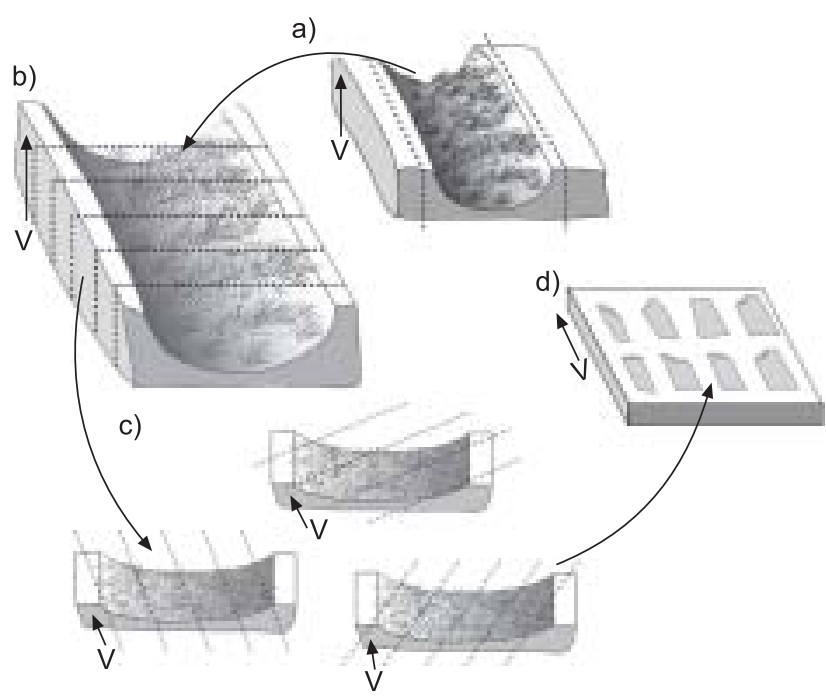

FIGURE 5. a) Fractionator sampling of a conducting airway generation bisected longitudinally and laid flat with the luminal surface up to generate local vertical sections. b) The bisected airway is cut into six strips of tissue. c) Using a random start, every other strip is selected and the strips are cut into small blocks that are cut following a random rotation of the cutting angle. d) Eight blocks are selected using a random start and every other block is selected for embedding and by maintaining vertical direction $(\mathrm{V})$ in the embedding mould. $\mathrm{V}$ is indicated by the arrow.

surface and length densities, have also been derived [117] Some simple guidelines will usually suffice for stereological sample size within an animal (primary sampling unit) as follows: 100-200 probe interactions (e.g. point hits), 50 fields and 10 blocks.

While 100-200 point hits per animal seems to be minimal sampling, 50 fields and 10 blocks seems to be over-sampling per animal. However, if the principle of doing more less well [114] is applied, then samples are taken widely within the organ, and 10 small blocks (selected by a smooth fractionator) are embedded into one block; thus only one section is cut per animal and the 50 fields and 100-200 point hits are sampled throughout the 10 blocks [112]. This sampling approach is not only precise but also highly efficient, especially when a computer-assisted approach with an automated microscope is used [118].

\section{CONCLUSIONS}

Stereological methods are extremely useful in defining changes in the epithelial-mesenchymal trophic unit where all of the compartments interact with each other, especially in asthma. These methods are also useful in comparisons between animals, airway generations and regions within individual airway generations. They allow comparisons of airway-specific responses of compartments between different species, such as humans, nonhuman primates and rodents. Through these precise stereological measurements, it has been established that the unique responses to inhaled allergens in nonhuman primates make it the most appropriate animal model of human asthma. 


\section{ACKNOWLEDGEMENTS}

Development of the rhesus monkey as a model for allergic airways disease was the product of the interactions of all of faculty and staff members of the Respiratory Diseases Unit at the California National Primate Research Center, whose members, in addition to the authors of the present abstract, include the following: B.K. Tarkington, V.J. Wong, L.F. Putney, J.L. Usachencho, M.Y. Stovall, J.E. Gerriets, V.F. Walby, J. Bric, T.R. Duvall, K. Kott, D. Morin, A. Weir and S.J. Nishio. The support of Primate Services at the California National Primate Research Center for Animal Handling, Care and Coordination and Veterinary Care, especially the efforts of L. Brignolo, K. Christe, S. Davis and B. Rodello were crucial to the present study and are gratefully acknowledged. S. M. Smiley-Jewell is also thanked for editing the manuscript.

\section{REFERENCES}

1 American Thoracic Society. Adult Asthma and Asthma and Children Fact Sheet. New York, American Thoracic Society, 2005.

2 World Health Organization. Bronchial asthma. Fact sheet number 307. Geneva, World Health Organization, 2006.

3 Centers for Disease Control and Prevention, National Center for Health Statistics. Asthma Prevalence, Health Care Use and Mortality, 2002. www.cdc.gov/nchs/ products/pubs/pubd/hestats/asthma/asthma.htm. Date last updated: January 11, 2007. Date last accessed: March 28, 2007.

4 Evans MJ, Van Winkle LS, Fanucchi MV, Plopper CG. The attenuated fibroblast sheath of the respiratory tract epithelial-mesenchymal trophic unit. Am J Respir Cell Mol Biol 1999; 21: 655-657.

5 Holgate ST, Davies DE, Lackie PM, Wilson SJ, Puddicombe SM, Lordan JL. Epithelial-mesenchymal interactions in the pathogenesis of asthma. J Allergy Clin Immunol 2000; 105: 193-204.

6 Avdalovic M, Usachenko J, Tyler NK, et al. Vascular remodeling is airway generation specific in primate model of chronic asthma. Am J Respir Crit Care Med 2006; 174: 1069-1076.

7 Paige R, Plopper C. Acute and chronic effects of ozone in animal models. In: Holgate ST, ed. Air Pollution and Health. New York, Academic Press, 1999; pp. 531-557.

8 Plopper CG, Hyde DM. Epithelial cells of bronchioles. In: Parent RA, ed. Treatise on Pulmonary Toxicology. Comparative Biology of the Normal Lung. Boco Raton, CRC Press, Inc., 1991; pp. 85-92.

9 Mariassy AT. Epithelial cells of trachea and bronchi. In: Parent RA, ed. Treatise on Pulmonary Toxicology: Comparative Biology of the Normal Lung. Boco Raton, CRC Press, 1991; pp. 63-76.

10 McBride JT. Architecture of the tracheobronchial tree. In: Parent RA, ed. Treatise on Pulmonary Toxicology: Comparative Biology of the Normal Lung. Boco Raton, CRC Press, 1991; pp. 49-61.

11 Tyler WS, Julian MD. Gross and subgross anatomy of lungs, pleura, connective tissue septa, distal airways, and structural units. In: Parent RA, ed. Treatise on Pulmonary Toxicology: Comparative Biology of the Normal Lung. Boco Raton, CRC Press, 1991; pp. 37-48.
12 Mercer RR, Crapo JD. Architecture of the acinus. In: Parent RP, ed. Treatise on Pulmonary Toxicology: Comparative Biology of the Normal Lung. Boco Raton, CRC Press, 1991; pp. 109-119.

13 Van Winkle LS, Fanucchi MV, Miller LA, et al. Epithelial cell distribution and abundance in rhesus monkey airways during postnatal lung growth and development. J Appl Physiol 2004; 97: 2355-2363.

14 Harkema JR, Mariassy AT, St George JA, Hyde DM, Plopper CG. Epithelial cells of the conducting airways: a species comparison. In: Farmer SG, Hay DW, eds. The Airway Epithelium: Physiology, Pathophysiology and Pharmacology. New York, Marcel Dekker, Inc., 1991; pp. 3-39.

15 Hyde DM, Hubbard WC, Wong V, Wu R, Pinkerton KE, Plopper CG. Ozone-induced acute tracheobronchial epithelial injury: relationship to granulocyte emigration in the lung. Am J Respir Cell Mol Biol 1992; 6: 481-497.

16 Mercer RR, Russell ML, Roggli VL, Crapo JD. Cell number and distribution in human and rat airways. Am J Respir Cell Mol Biol 1994; 10: 613-624.

17 Plopper CG, Hatch GE, Wong V, et al. Relationship of inhaled ozone concentration to acute tracheobronchial epithelial injury, site-specific ozone dose, and glutathione depletion in rhesus monkeys. Am J Respir Cell Mol Biol 1998; 19: 387-399.

18 StGeorge JA, Harkema JR, Hyde DM, Plopper CG. Cell populations and structure/function relationships of cells in the airways. In: Gardner DE, Crapo JD, Massaro EJ, eds. Toxicology of the Lung. New York, Raven Press, 1988; pp. 71-102.

19 StGeorge JA, Wang S. Secretory glycoconjugates of trachea and bronchi. In: Parent RA, ed. Treastise on Pulmonary Toxicology: Comparative Biology of the Normal Lung. Boco Raton, FL, CRC Press, Inc., 1991; pp. 77-83.

20 Spicer SS. Diamine methods for differentialing mucosubstances histochemically. J Histochem Cytochem 1965; 13: 211-234.

21 Heidsiek JG, Hyde DM, Plopper CG, StGeorge JA. Quantitative histochemistry of mucosubstance in tracheal epithelium of the macaque monkey. J Histochem Cytochem 1987; 35: 435-442.

22 Plopper CG, Weir A, StGeorge JA, et al. Cell populations and the respiratory system: interspecies diversity in composition, distribution, and morphology. In: Dungworth D, Kimmerle G, Lewkowski R, McClennan R, Stober W, eds. Inhalation Toxicology. New York, Springer, 1988; pp. 25-40.

23 Plopper CG, Weir AJ, Nishio SJ, Cranz DL, StGeorge JA. Tracheal Submucosal Gland Development in the Rhesus Monkey, Macaca Mulatta: Ultrastructure and Histochemistry. Anat Embryol 1986; 174: 167-178.

24 Plopper CG, Alley JL, Weir AJ. Differentiation of tracheal epithelium during fetal lung maturation in the rhesus monkey Macaca mulatta. Am J Anat 1986; 175: 59-71.

25 Bucher U, Reid L. Development of the mucus-secreting elements in human lung. Thorax 1961; 16: 219-225.

26 Thurlbeck WM, Benjamin B, Reid L. Development and distribution of mucous glands in the foetal human trachea. Br J Dis Chest 1961; 55: 54-64. 
27 Evans MJ, Fanucchi MV, Van Winkle LS, et al. Fibroblast growth factor-2 during postnatal development of the tracheal basement membrane zone. Am J Physiol Lung Cell Mol Physiol 2002; 283: L1263-L1270.

28 Brewster CE, Howarth PH, Djukanovic R, Wilson J, Holgate ST, Roche WR. Myofibroblasts and subepithelial fibrosis in bronchial asthma. Am J Respir Cell Mol Biol 1990; 3: 507-511.

29 Roche WR, Beasley R, Williams JH, Holgate ST. Subepithelial fibrosis in the bronchi of asthmatics. Lancet 1989; 1: 520-524.

30 Gaultier C, Girard F. Normal and pathological lung growth: structure-function relationships. Bull Eur Physiopathol Respir 1980; 16: 791-842.

31 Sward-Comunelli SL, Mabry SM, Truog WE, Thibeault DW. Airway muscle in preterm infants: changes during development. J Pediatr 1997; 130: 570-576.

32 Hislop AA, Haworth SG. Airway size and structure in the normal fetal and infant lung and the effect of premature delivery and artificial ventilation. Am Rev Respir Dis 1989; 140: 1717-1726.

33 Tran MU, Weir AJ, Fanucchi MV, et al. Smooth muscle development during postnatal growth of distal bronchioles in infant rhesus monkeys. J Appl Physiol 2004; 97: 2364-2371.

34 Daniel FB, Schut HAJ, Sandwisch DW, et al. Interspecies comparisons of benzo(a)pyrene metabolism and DNAadduct formation in cultured human and animal bladder and tracheobronchial tissues. Cancer Res 1983; 43: 4723-4729.

35 Lee C, Watt KC, Chang AM, Plopper CG, Buckpitt AR, Pinkerton KE. Site-selective differences in cytochrome P450 isoform activities. Comparison of expression in rat and rhesus monkey lung and induction in rats. Drug Metab Dispos 1998; 26: 396-400.

36 Yueh MF, Krueger SK, Williams DE. Pulmonary flavincontaining monooxygenase (FMO) in rhesus macaque: expression of FMO2 protein, mRNA and analysis of the cDNA. Biochim Biophys Acta 1997; 1350: 267-271.

37 Krueger SK, Martin SR, Yueh MF, Pereira CB, Williams DE. Identification of active flavin-containing monooxygenase isoform 2 in human lung and characterization of expressed protein. Drug Metab Dispos 2002; 30: 34-41.

38 Choi HK, Finkbeiner WE, Widdicombe JH. A comparative study of mammalian tracheal mucous glands. J Anat 2000; $197 \mathrm{Pt}, 3$ : 361-372.

39 Plopper CG, Heidsiek JG, Weir AJ, St George JA, Hyde DM. Tracheobronchial epithelium in the adult rhesus monkey: A quantitative histochemical and ultrastructural study. Am J Anat 1989; 184: 31-40.

40 StGeorge JA, Cranz DL, Zicker S, Etchison JR, Dungworth DL, Plopper CG. An immunohistochemical characterization of rhesus monkey respiratory secretions using monoclonal antibodies. Am Rev Respir Dis 1985; 132: 556-563.

41 StGeorge JA, Nishio SJ, Plopper CG. Carbohydrate cytochemistry of the rhesus monkey tracheal epithelium. Anat Rec 1984; 210: 293-302.

42 StGeorge JA, Nishio SJ, Cranz DL, Plopper CG. Carbohydrate cytochemistry of rhesus monkey submucosal glands. Anat Rec 1986; 216: 60-67.
43 Dupuit F, Bout A, Hinnrasky J, et al. Expression and localization of CFTR in the rhesus monkey surface airway epithelium. Gene Ther 1995; 2: 156-163.

44 Huang TH, StGeorge JA, Plopper CG, Wu R. Keratin protein expression during the development of conducting airway epithelium in nonhuman primates. Differentiation 1989; 41: 78-86.

45 Tyler NK, Hyde DM, Hendrickx AG, Plopper CG. Morphogenesis of the respiratory bronchiole in rhesus monkey lungs. Am J Anat 1988; 182: 215-223.

46 Tyler NK, Hyde DM, Hendrickx AG, Plopper CG. Cytodifferentiation of two epithelial populations of the respiratory bronchiole during fetal lung development in the rhesus monkey. Anat Rec 1989; 225: 297-309.

47 An G, Luo G, Wu R. Expression of MUC2 gene is downregulated by vitamin $\mathrm{A}$ at the transcriptional level in vitro in tracheobronchial epithelial cells. Am J Respir Cell Mol Biol 1994; 10: 546-551.

48 Huang TH, Ann DK, Zhang YJ, Chang AT, Crabb JW, $\mathrm{Wu}$ R. Control of keratin gene expression by vitamin A in tracheobronchial epithelial cells. Am J Respir Cell Mol Biol 1994; 10: 192-201.

49 An G, Huang TH, Tesfaigzi J, et al. An unusual expression of a squamous cell marker, small proline-rich protein gene, in tracheobronchial epithelium: differential regulation and gene mapping. Am J Respir Cell Mol Biol 1992; 7: 104-111.

50 An G, Tesfaigzi J, Carlson DM, Wu R. Expression of a squamous cell marker, the spr1 gene, is posttranscriptionally down-regulated by retinol in airway epithelium. J Cell Physiol 1993; 157: 562-568.

51 An G, Tesfaigzi J, Chuu YJ, Wu R. Isolation and characterization of the human spr1 gene and its regulation of expression by phorbol ester and cyclic AMP. J Biol Chem 1993; 268: 10977-10982.

52 An G, Wu R. Thioredoxin gene expression is transcriptionally up-regulated by retinol in monkey conducting airway epithelial cells. Biochem Biophys Res Commun 1992; 183: $170-175$.

53 Chang MM, Harper R, Hyde DM, Wu R. A novel mechanism of retinoic acid-enhanced interleukin-8 gene expression in airway epithelium. Am J Respir Cell Mol Biol 2000; 22: 502-510.

54 Miller LA, Cheng LZ, Wu R. Inhibition of epidermal growth factor-like growth factor secretion in tracheobronchial epithelial cells by vitamin A. Cancer Res 1993; 53: 2527-2533.

55 An G, Wu R. cDNA cloning of a hnRNP A1 isoform and its regulation by retinol in monkey tracheobronchial epithelial cells. Biochim Biophys Acta 1993; 1172: 292-300.

56 Martin WR, Brown C, Zhang YJ, Wu R. Growth and differentiation of primary tracheal epithelial cells in culture: regulation by extracellular calcium. I Cell Physiol 1991; 147: 138-148.

57 Lloyd CM, Gonzalo JA, Coyle AJ, Gutierrez-Ramos JC. Mouse models of allergic airway disease. Adv Immunol 2001; 77: 263-295.

58 Bates J, Irvin C, Brusasco V, et al. The use and misuse of Penh in animal models of lung disease. Am J Respir Cell Mol Biol 2004; 31: 373-374. 
59 Wagers S, Lundblad LK, Ekman M, Irvin CG, Bates JH. The allergic mouse model of asthma: normal smooth muscle in an abnormal lung? J Appl Physiol 2004; 96: 2019-2027.

60 Boyce JA, Austen KF. No audible wheezing: nuggets and conundrums from mouse asthma models. J Exp Med 2005; 201: 1869-1873.

61 Corry DB, Grunig G, Hadeiba H, et al. Requirements for allergen-induced airway hyperreactivity in $\mathrm{T}$ and $\mathrm{B}$ celldeficient mice. Mol Med 1998; 4: 344-355.

62 Wegmann M, Fehrenbach H, Fehrenbach A, et al. Involvement of distal airways in a chronic model of experimental asthma. Clin Exp Allergy 2005; 35: 1263-1271.

63 Snibson KJ, Bischof RJ, Slocombe RF, Meeusen EN. Airway remodelling and inflammation in sheep lungs after chronic airway challenge with house dust mite. Clin Exp Allergy 2005; 35: 146-152.

64 Out TA, Wang SZ, Rudolph K, Bice DE. Local T-cell activation after segmental allergen challenge in the lungs of allergic dogs. Immunology 2002; 105: 499-508.

65 Gundel RH, Wegner CD, Letts LG. Antigen-induced acute and late-phase responses in primates. Am Rev Respir Dis 1992; 146: 369-373.

66 Schelegle ES, Gershwin LJ, Miller LA, et al. Allergic asthma induced in rhesus monkeys by house dust mite (Dermatophagoides farinae). Am J Pathol 2001; 158: 333-341.

67 van Scott MR, Hooker JL, Ehrmann D, et al. Dust miteinduced asthma in cynomolgus monkeys. J Appl Physiol 2004; 96: 1433-1444.

68 Weiszer I, Patterson R, Pruzansky JJ. Ascaris hypersensitivity in the rhesus monkey. I. A model for the study of immediate type hypersensitity in the primate. J Allergy 1968; 41: 14-22.

69 Yasue M, Nakamura S, Yokota T, Okudaira H, Okumura Y. Experimental monkey model sensitized with mite antigen. Int Arch Allergy Immunol 1998; 115: 303-311.

70 Fanucchi MV, Plopper CG, Evans MJ, et al. Cyclic exposure to ozone alters distal airway development in infant rhesus monkeys. Am J Physiol Lung Cell Mol Physiol 2006; 291: L644-L650.

71 NIH Nonhuman Primate Reagent Resource. http:// nhpreagents.bidmc.harvard.edu/NHP/default.aspx. Date last accessed: March 28, 2007.

72 Coffman RL, Hessel EM. Nonhuman primate models of asthma. J Exp Med 2005; 201: 1875-1879.

73 Miller LA, Hurst SD, Coffman RL, et al. Airway generation-specific differences in the spatial distribution of immune cells and cytokines in allergen-challenged rhesus monkeys. Clin Exp Allergy 2005; 35: 894-906.

74 Reader JR, Tepper JS, Schelegle ES, et al. Pathogenesis of mucous cell metaplasia in a murine asthma model. Am J Pathol 2003; 162: 2069-2078.

75 Cutz E, Levinson H, Cooper DM. Ultrastructure of airways in children with asthma. Histopathology 1978; 2: 407-421.

76 Laitinen LA, Heino M, Laitinen A, Kava T, Haahtela T. Damage of the airway epithelium and bronchial reactivity in patients with asthma. Am Rev Respir Dis 1985; 131: 599-606.

77 Hogg JC. The pathology of asthma. Clin Chest Med 1984; 5: 567-571.
78 Montefort S, Herbert CA, Robinson C, Holgate ST. The bronchial epithelium as a target for inflammatory attack in asthma. Clin Exp Allergy 1992; 22: 511-520.

79 Erjefalt JS, Persson CG. Airway epithelial repair: breathtakingly quick and multipotentially pathogenic. Thorax 1997; 52: 1010-1012.

80 Shebani E, Shahana S, Janson C, Roomans GM. Attachment of columnar airway epithelial cells in asthma. Tissue Cell 2005; 37: 145-152.

81 Shahana S, Bjornsson E, Ludviksdottir D, et al. Ultrastructure of bronchial biopsies from patients with allergic and non-allergic asthma. Respir Med 2005; 99: 429-443.

82 Ordonez CL, Khashayar R, Wong HH, et al. Mild and moderate asthma is associated with airway goblet cell hyperplasia and abnormalities in mucin gene expression. Am J Respir Crit Care Med 2001; 163: 517-523.

83 Evans MJ, Fanucchi MV, Plopper CG. The basement membrane zone in asthma. Curr Respir Med Rev 2006; 2: 331-337.

84 Evans MJ, Guha SC, Cox RA, Moller PC. Attenuated fibroblast sheath around the basement membrane zone in the trachea. Am J Respir Cell Mol Biol 1993; 8: 188-192.

85 Fine JD. Structure and antigenicity of the skin basement membrane zone. J Cutan Pathol 1991; 18: 401-409.

86 Uitto J, Pulkkinen L. Molecular complexity of the cutaneous basement membrane zone. Mol Biol Rep 1996; 23: $35-46$.

87 Evans MJ, Van Winkle LS, Fanucchi MV, et al. Fibroblast growth factor-2 in remodeling of the developing basement membrane zone in the trachea of infant rhesus monkeys sensitized and challenged with allergen. Lab Invest 2002; 82: 1747-1754.

88 Bousquet J, Jeffery PK, Busse WW, Johnson M, Vignola AM. Asthma. From bronchoconstriction to airways inflammation and remodeling. Am J Respir Crit Care Med 2000; 161: 1720-1745.

89 Milanese M, Crimi E, Scordamaglia A, et al. On the functional consequences of bronchial basement membrane thickening. J Appl Physiol 2001; 91: 1035-1040.

90 Adachi E, Hopkinson I, Hayashi T. Basement-membrane stromal relationships: interactions between collagen fibrils and the lamina densa. Int Rev Cytol 1997; 173: 73-156.

91 Sannes PL, Wang J. Basement membranes and pulmonary development. Exp Lung Res 1997; 23: 101-108.

92 Sannes PL, Burch KK, Khosla J, McCarthy KJ, Couchman JR. Immunohistochemical localization of chondroitin sulfate, chondroitin sulfate proteoglycan, heparan sulfate proteoglycan, entactin, and laminin in basement membranes of postnatal developing and adult rat lungs. Am J Respir Cell Mol Biol 1993; 8: 245-251.

93 Evans MJ, Fanucchi MV, Baker GL, et al. Atypical development of the tracheal basement membrane zone of infant rhesus monkeys exposed to ozone and allergen. Am J Physiol Lung Cell Mol Physiol 2003; 285: L931-L939.

94 Evans MJ, Fanucchi MV, Baker GL, et al. The remodelled tracheal basement membrane zone of infant rhesus monkeys after 6 months of recovery. Clin Exp Allergy 2004; 34: 1131-1136.

95 Lee SY, Kim JS, Lee JM, et al. Inhaled corticosteroid prevents the thickening of airway smooth muscle in 
murine model of chronic asthma. Pulm Pharmacol Ther 2007; (In press).

96 Ebina M, Takahashi T, Chiba T, Motomiya M. Cellular hypertrophy and hyperplasia of airway smooth muscles underlying bronchial asthma. A 3-D morphometric study. Am Rev Respir Dis 1993; 148: 720-726.

97 Stephens NL, Jiang H, Xu J, Kepron W. Airway smooth muscle mechanics and biochemistry in experimental asthma. Am Rev Respir Dis 1991; 143: 1182-1188.

98 Stephens NL, Jiang H, Halayko A. Role of airway smooth muscle in asthma: possible relation to the neuroendocrine system. Anat Rec 1993; 236: 152-163.

99 Bramley AM, Thomson RJ, Roberts CR, Schellenberg RR. Hypothesis: excessive bronchoconstriction in asthma is due to decreased airway elastance. Eur Respir J 1994; 7: 337-341.

100 Tran MU, Weir AJ, Fanucchi MV, et al. Smooth muscle hypertrophy in distal airways of sensitized infant rhesus monkeys exposed to house dust mite allergen. Clin Exp Allergy 2004; 34: 1627-1633.

101 Hoshino M, Nakamura Y, Hamid QA. Gene expression of vascular endothelial growth factor and its receptors and angiogenesis in bronchial asthma. J Allergy Clin Immunol 2001; 107: 1034-1038.

102 Lee CG, Link H, Baluk P, et al. Vascular endothelial growth factor (VEGF) induces remodeling and enhances $\mathrm{T}(\mathrm{H}) 2$-mediated sensitization and inflammation in the lung. Nat Med 2004; 10: 1095-1103.

103 Hogg JC, Pare PD, Moreno R. The effect of submucosal edema on airways resistance. Am Rev Respir Dis 1987; 135: S54-S56.

104 McFadden ER Jr. Hypothesis: exercise-induced asthma as a vascular phenomenon. Lancet 1990; 335: 880-883.

105 Cabanes LR, Weber SN, Matran R, et al. Bronchial hyperresponsiveness to methacholine in patients with impaired left ventricular function. N Engl J Med 1989; 320: 1317-1322.

106 Hyde DM, Plopper CG, Kass PH, Alley JL. Estimation of cell numbers and volumes of bronchiolar epithelium during rabbit lung maturation. Am J Anat 1983; 167 359-370.

107 Sterio DC. The unbiased estimation of number and sizes of arbitrary particles using the disector. J Microsc 1984; 134: 127-136.

108 Hyde DM, Miller LA, McDonald RJ, et al. Neutrophils enhance clearance of necrotic epithelial cells in ozoneinduced lung injury in rhesus monkeys. Am J Physiol 1999; 277: L1190-L1198.

109 Postlethwait EM, Joad JP, Hyde DM, et al. Threedimensional mapping of ozone-induced acute cytotoxicity in tracheobronchial airways of isolated perfused rat lung. Am J Respir Cell Mol Biol 2000; 22: 191-199.

110 Gundersen HJ. Notes on the estimation of numerical density of arbitrary profiles: the edge effect. J Microsc 1977; 111: 219-223.

111 Gundersen HJ. The smooth fractionator. J Microsc 2002; 207: 191-210.

112 Hyde DM, Tyler NK, Putney LF, Singh P, Gundersen HJ. Total number and mean size of alveoli in mammalian lung estimated using fractionator sampling and unbiased estimates of the Euler characteristic of alveolar openings. Anat Rec 2004; 277A: 216-226.

113 Baddeley AJ, Gundersen HJ, Cruz-Orive LM. Estimation of surface area from vertical sections. J Microsc 1986; 142: 259-276.

114 Gundersen HJ, Osterby R. Optimizing sampling efficiency of stereological studies in biology: or "do more less well!". J Microsc 1981; 121: 65-73.

115 Cruz-Orive LM. Precision of Cavalieri sections and slices with local errors. J Microsc 1999; 193: 182-198.

116 Gundersen HJ, Jensen EB. The efficiency of systematic sampling in stereology and its prediction. J Microsc 1987; 147: 229-263.

117 Cruz-Orive LM. Best linear unbiased estimators for stereology. Biometrics 1980; 36: 595-605.

118 Gundersen HJ, Jensen EB, Kieu K, Nielsen J. The efficiency of systematic sampling in stereology - reconsidered. J Microsc 1999; 193: 199-211. 